brazilianpoliticalsciencereview

B OOK REVIEW

\title{
The Democratic Deficit of Brazilian Foreign Policy: a Faorian Interpretation*
}

\author{
Mónica Salomón \\ Universidade Federal de Santa Catarina, Brazil
}

(LOPES, Dawisson Belém. Política externa e democracia no Brasil. São Paulo: UNESP, 2013)

rebraction raditionally conceived as a singular, differentiated policy insulated from public debate, foreign policy in democratic political systems has gradually drawn closer to other public policies. Mechanisms for channelling the demands of different political actors and even for direct participation in developing and executing foreign policy, as well as mechanisms of control and accountability, have been established and have moved the democratisation of foreign policy forward to a greater or lesser degree, according to the context. However, an examination of the literature shows that in foreign policy the democratic deficit is invariably perceived as greater than in domestic policies. To what can this be attributed? To the inertia of tradition or to a real specificity of foreign policy, in which debate might not be advisable? In the words of Christopher Hill (2003), this specificity is related to the "long-debated issue of how far foreign policy can or should be accountable to citizens who are probably ignorant of the issues but who may ultimately be asked to die in its name" (2003, p.17). For many, the tension between two types of Weberian rationality (purposeful rationality and valueoriented rationality) is particularly important in foreign policy.

If the topic of the democratisation of foreign policy is of universal interest, it is particularly interesting in contemporary Brazil. As Ambassador (and former Minister of External Relations) Celso Amorim states in the book's prologue, Brazilian foreign policy is increasingly present in public debate in Brazil and has therefore become another field of party conflict. At the same time, several institutional changes, within and without the Itamaraty (Ministry of External Relations), have assuaged the traditional insulation of the bureaucracy responsible for conducting Brazil's foreign policy.

That is why Dawisson Belém Lopes's work, based on his Ph.D thesis defended at IUPERJ (Instituto Universitário de Pesquisas do Rio de Janeiro - University Research Institute of Rio de Janeiro) in 2010, is a most welcome contribution to this debate. It is a book of great interest and numerous virtues. Perhaps the greatest one is its eclecticism, the decision to combine analytic perspectives originating from different academic fields, as well as the attempt to balance social explanation with historical interpretation. The author's clear commitment to the objective of democratising Brazilian foreign policy is also laudable. On the other hand, the book displays many irregularities and frailties common in the work of junior researchers. This is particularly noticeable in the research design. 
Indeed, the author's initial statement about what his research problem is, "to point out the potentialities and limitations of the proposal to democratise BFP [Brazilian Foreign Policy]" (p.28), does not help him to channel his efforts in a more focused and productive way. A research problem necessarily seeks to describe or explain an existing phenomenon. Without that, there is no analysis. Although it is perfectly valid to ask oneself about the possibilities of something happening, it is a purely speculative exercise, rather than an analytical one. In any case, it is an exercise dependent on a prior analysis. And this prior analysis requires an adequate and precise formulation of the problem to be analysed, in this case, a certain aspect of BFP or of the democratisation of BFP. In the absence of this, the focus changes throughout the book, addressing several different questions, which are not always made explicit or explored in much depth.

In Chapter 1, the literature on models of foreign policy analysis is briefly examined. In a very summary fashion (sometimes based on a brief quotation), the author presents several contributions by authors who have dealt with foreign policy from more traditional perspectives (starting from Morgenthau's), and those part of the canon of the sub-area of Foreign Policy Analysis, from precursors Snyder, Burton and Sapin to contemporary authors such as Milner or Moravcsik. The aim of this exercise is to seek answers to understand what could be termed the "democratic deficit" of BFP - the reasons for which "it is not subject to democratic control by the population, as what happens in principle (or should happen) with any public policy" (p.16). Different connections between foreign policy and public democracy/ opinion are made, but not in a very systematic way. It is hard for the reader to identify the author's own arguments and voice, as he does not always assume a clear position in relation to the authors/models he presents.

Chapter 2 proposes to "[retrieve], from a historiographical perspective, the rudiments of the democratisation process in the discourse and practice of Brazil's foreign policy from 1985" (p.29). Statements by different Ministers of External Relations and other Itamaraty documents with mentions of the theme of democratisation of BFP are analysed. The author also reviews some institutional changes that can be seen as advances (or not) towards democratisation, for example, the creation of new dialogue channels with several BFP stakeholders - such as mayors, governors, representatives from social movements and academics - during the Lula government. Here, it would have been interesting to have gone beyond the official narrative and further into the genesis of and the debate on these "Itamaratyan" proposals, and to have left the Itamaraty context aside to analyse, for example, the foreign policy proposals of candidates to the presidency or the institutional changes that affect BFP in other ministries. The methodological decision to leave open the concept of democratisation in foreign policy seems, in the least, questionable.

Of a more theoretical nature, Chapter 3 is also affected by the lack of definition of the research problem. The chapter's aim is to examine "the hypothesis that democracy is compatible with foreign policy in many of its aspects" (p.84). In truth, this statement is not a hypothesis as such (it does not explain anything) and, in any case, it is a trivial one. The chapter is structured around four groups of questions (which the author calls historical, technocratic, institutionalist and normative, respectively) that include a quite heterogeneous set of facts, arguments and debates on the relation between democratisation and foreign policy. In spite of the problem's lack of definition and the questionable categorisation (the categories overlap), the chapter turns out to be very instructive and interesting. Some of the topics dealt with are the consolidation of diplomacy as an international institution in the 17th century; the development of the public management sector in the 19th and 20th centuries; technocratic ideology contrasted with democratic demands; the role of the Legislative Branch 
in foreign policy; and contemporary proposals to reconcile the democratic decision-making method with foreign policies that turn out effective.

In Chapter 4, the author delves into the "book's central avenue" (p.142), to use his own words. The starting point is a question with good potential to give the whole book focus, and which could (and should) have been formulated from the outset: why did it [the democratisation of foreign policy] not happen in Brazil after democratisation? The author proposes to answer this question by comparing the Brazilian case to those of European and North American countries. Initially, the idea of using a comparative method seems to be quite a sensible methodological strategy. Unfortunately, the comparison boils down to a collection of quotes from different studies by different authors about certain countries (Switzerland, United Kingdom, Norway, Canada, the United States, France and Germany), and it is unclear what exactly is being compared in each case and even less clear on which data the comparison is based. The alleged difference of the European and Anglo-Saxon models indicated by the author may have a basis, but it is certainly not found in the data presented. Instead of resorting to secondary sources and using them in an impressionistic fashion, the author could have utilised, for example, the Eurobarometer or other existing statistical sources. In any case, no hypothesis on Brazil's difference arises from the comparison to other countries. In the same chapter, he examines the hypothesis present in BFP literature regarding the lack of development of Brazilian democracy, once again grouped into four categories: apathy of public opinion, "developmentalist government induction" (the idea that the government foments the bureaucratic isolation of foreign policy so as to better focus on the developmentalist goal), the organizational culture of the Itamaraty, and the constraint of political-administrative institutions. Although the four hypothesis are qualified by the author as "ambivalent and inconclusive regarding the root of the phenomenon" (p.207), in our view, the part of the chapter devoted to discussing them is one of the book's high points.

The author's own hypothesis on the lack of development of BFP is presented in the fifth and final chapter. He turns to the concept of "aristocratic republicanism" (based on the political experience of the Italian Renaissance republics) combined with the concept of "bureaucratic stratum" introduced by Raymundo Faoro in The Owners of Power (1958) to postulate, as the main explanatory element, the existence of a "BFP stratum" very resistant to the demands of democratisation, although pressured in the last few years by democratising forces, which may have given rise to a "mitigated republicanism". The strongly patrimonialist Portuguese heritage and colonial centralisation, as well as the actual threat of political disintegration as a consequence of the dismantling of the Portuguese colonial apparatus, are some of the elements the author uses to weave his interpretation, which is, in fact, compatible with several elements of interpretations by other authors presented in the previous chapter. Once again, the author moves with ease through several terrains, combining in an attractive manner the political thought of Machiavelli, the Faorian interpretation of Brazilian social history and other traditional and contemporary sources.

Although unanswered, the initial question about the possibilities and limitations of BFP is addressed once again in the conclusion of this at once irregular and stimulating study.

\section{References}

FAORO, Raymundo (1958), Os donos do poder: formação do patronato político brasileiro. Porto Alegre, Rio de Janeiro, São Paulo: Ed. Globo.

HILL, Christopher (2003), The Changing Politics of Foreign Policy. Londres: Palgrave. 